Volume: 01 Issue: 03 | November -2019

ISSN: 2663-8525

Received: 02.11.2019; Accepted 07.11.2019; Published: 05.12.2019 at www.editoncpublishing.org

Ngeno, D.K. et al., Editon Cons. J. Arts., Humanit. S. Stud., Double -Blind Peer Reviewed Journal

\title{
Influence of Appropriate Physical Resources on Retention of Pupils with Disabilities in Mainstreamed Primary Schools in Bomet County, Kenya
}

\author{
Daniel Kipkirui Ngeno', Prof. Frederick Ngala², Prof. Henry K. Kiplangat ${ }^{3}$ \\ 1,2,3 Kabarak University, Kenya \\ Main Author's Email address: danielngeno1@gmail.com
}

\begin{abstract}
This research sought to find out the influence of appropriate physical resources on retention of pupils with disabilities in mainstreamed Primary Schools in Bomet County, Kenya. The challenge this study sought to address was low retention of Pupils with Disabilities (PWDs) in mainstreamed schools. This study was embedded in Systems Theory by Von Bertalanffy (1968). It adopted a survey research design. The target population was 840 teachers. Yamane formula was employed to get a sample size of 271 teachers. Multi-stage sampling procedure was applied. The findings of the study revealed that appropriate physical resources significantly influenced the retention of PWDs by $=19.2 \%(p<0.05)$. The study also reports a positive and statistically significant relationship between physical resources and retention of pupils with disabilities $(r=$ $0.828, \mathrm{p}<0.05)$. The study concludes that the supply of appropriate resources remains a major factor that promotes retention of pupils with disabilities. This means that when appropriate physical resources are provided to pupils with disabilities, their retention of pupils with disabilities in mainstreamed schools improve. However, a lack of these resources has been proven through the findings of this research that they cause drop out of PWDs from their schools. The study recommended that appropriate physical resources such as classrooms, toilets, dining halls, dormitories, laboratories and libraries in order to promote retention of pupils with disabilities be provided by school administrators.
\end{abstract}

Key Terms: Appropriate, Physical Resources, Retention, Disabilities.

$--* * *$

How to cite this article in APA ( $6^{\text {th }}$ Edition)

Ngeno, D.K., Ngala,F., \& Kiplangat, H. K. (2019). Influence of appropriate physical resources on retention of pupils with disabilities in mainstreamed primary schools in Bomet County, Kenya. Editon

Cons. J. Arts., Humanit. S. Stud., 1(3), 134-142. $* * *$ 


\section{Editon Consortium Journal of Arts, Humanities and Social Studies (ECJAHSS)}

Volume: 01 Issue: 03 | November -2019

ISSN: 2663-8525

Received: 02.11.2019; Accepted 07.11.2019; Published: 05.12.2019 at www.editoncpublishing.org

Ngeno, D.K. et al., Editon Cons. J. Arts., Humanit. S. Stud., Double -Blind Peer Reviewed Journal

\section{Introduction}

Mainstreamed learning is a new initiative that encompasses children with disabilities in a regular teaching and learning centre. Mainstreaming policy is concerned with overcoming barriers that hinder children from free participation in common learning activities (MacGuine \& Molbjerg, 2011). Friendly learning environment encourages children with disabilities to participate in education mainstreamed learning institutions. The report by Walsh and Thomas (2015) reiterate that when education managers fail to provide appropriate equipment needed, for example, hearing aide, vision aide, electronically adapted mobility devices among others, hamper retention of pupils with disabilities (PWDs). Lack of provision of these resources may be due to inadequate financial resources to facilitate the delivery of such resources and services which could enhance retention of learners with disabilities in public schools. Nevertheless, the report by Walsh and Thomas (2015) did not handle the provision of adequate trained teachers who are qualified for special needs education.

Retention of pupils with disabilities to learn in mainstreamed schools has remained a challenge in many societies. Khumalo and Hodgson (2015) aver that the South African Department of Basic Education showed that as many as 489,036 children with disabilities dropped out of school within a matter of four years. Kenya is not an exemption on issues pertaining to disability groups. Integrated programmes in mainstreamed schools are the way to go to accommodate learners with disabilities. The National Coordinating Agency for Population and Development and Kenya National Bureau of Statistics (2008) indicates an estimated figure of $4.6 \%$ as a total population of people who experience one form of disability or the other. People living with disabilities make up 10\% of the total population of Kenya. This percentage gives an approximation of 3.5 million people. It is approximated that only one out of six impaired children is privileged to attend a regular public school. Those few who are able to attend school face the familiar problems of exclusion and stigmatisation (Global Campaign for Education, 2014).

It has been a general concern for many people that children with disabilities need attention in all areas of life. According to the Ministry of Education sessional paper No. 4 of 2014, Kenya committed herself to see to it that the rights of persons with disabilities under the Persons with Disabilities Act, 2003 was adhered to. Kenya has ratified the UN Convention on the Rights of Persons with Disabilities. Article 25(1) of the Universal Declaration of Human Rights (1948) which specifically advocates for the socio-economic rights of people with disabilities. Equally, the Basic Education Act 2013 has emphasised the provision of quality early childhood education, basic education and transition to secondary education for all learners.

Furthermore, despite strides to accommodate inclusive schools with appropriate facilities, a study conducted by Kogei (2013) states that special needs education in Kenya is reported to suffer from inadequate resources relevant to PWDs to learn in their schools. Retention of pupils with disabilities still remains a challenge, as reported by the Bomet County Integrated Development Plan (2013). Research conducted by the National Council for Population and Development (2017) in Bomet County focused on the adequacy of learning facilities and other amenities. The research further found that out of every 10 pupils with disabilities admitted to an integrated school in any given year, only 3 were retained up to the completion level of primary education which necessitated this study. It is argued that pupils with disabilities experience significantly lower rates of primary school completion compared to their peers without disability (Filmer, 2008). This suggests that when appropriate resources are not provided for pupils with disabilities, their retention rates may be negatively affected. This exposition necessitated a study to 


\section{Editon Consortium Journal of Arts, Humanities and Social Studies (ECJAHSS)}

Volume: 01 Issue: 03 | November -2019

ISSN: $2663-8525$

Received: 02.11.2019; Accepted 07.11.2019; Published: 05.12.2019 at www.editoncpublishing.org

Ngeno, D.K. et al., Editon Cons. J. Arts., Humanit. S. Stud., Double -Blind Peer Reviewed Journal

be carried out so as to seek solutions to the problem by proving whether the predicted variables, when not catered for, were true hindrances to the retention of PWDs.

The background of this study shows that there is a problem of retention for pupils with disabilities in regular mainstreamed schools. Many children living with disabilities do not go to school at all. The magnitude of the problem of this study was displayed in that out of 5,121 children with various types of disabilities who were registered in various public mainstreamed schools, 3,159 were not retained in the years between 2014 and 2017. The table shows that only 1,962 were retained within a period of 4 years. According to the County Government of Bomet (2017), children with disabilities were not fully retained in public primary schools. It was further observed by the National Council for Population and Development (2017) that out of every 10 pupils with disabilities enrolled in integrated schools in Bomet County, only 3 remained to the completion level of basic education. In addition, a report from the County government of Bomet reinforces this information by stating that only $38 \%$ of PWDs were retained in regular mainstreamed schools while $62 \%$ did not remain to pursue their studies.

When children with disabilities fail to acquire universal basic education to empower them socially as required by the sustainable Millennium Development Goals, their living conditions remain deplorable. Pupils with disabilities, who are not retained to further their studies, tend to display poor performance in all aspects related to life as observed by Baxter and Babbie (2013). This research study sought to find out the influence of appropriate resources on retention of pupils with disabilities. The study was basically conducted in mainstreamed primary schools in Bomet County, Kenya.

\section{LITERATURE REVIEW} Appropriate Physical Resources and Retention of Pupils with Disabilities

Common learning for all children in mainstreamed schools is turning to be a day to day practice in society. According to Stough (2013), the Australian Government began to integrate learners with disabilities into mainstreamed classrooms in the 1970s. This happened after almost a century when the Country was educating children with disabilities in segregated settings. This was in response to research findings on the affairs of PWDs and their related effectiveness on special education settings. Not only that but also a shift in attitudes in the Western world towards how people with disabilities should be educated. Stough adds that the policy of mainstreaming in Australia is to mainstream learners with disabilities in regular classrooms wherever possible. Some children needed specialised adjustments, such as ramps, modified latrines, large print materials and Braille machines. The researcher also maintains that learners with similar disabilities were often transported to a school where such resources could be centralised. This again could not allow learners with various difficulties to attend to their regular neighbourhood schools.

It has been realised that some mainstreamed schools deny admission to many children. In China, Richardson (2013) states that children and youth with disabilities are always confronted with discrimination in schools. At times, they ask them to leave, especially when appropriate classroom accommodations are not provided to help them overpower barriers related to their disabilities. Learners in a mainstreamed school should be accorded relevant education and optimal opportunities for their individual enhancement in life. In Pakistan, the retention rate of PWDs in regular schools is slowly increasing. Nevertheless, basic school infrastructure continues to remain poor. District Information System for Education data indicates that the number of schools with ramps increased to $55.09 \%$ 


\section{Editon Consortium Journal of Arts, Humanities and Social Studies (ECJAHSS)}

Volume: 01 Issue: 03 | November -2019

ISSN: $2663-8525$

Received: 02.11.2019; Accepted 07.11.2019; Published: 05.12.2019 at www.editoncpublishing.org

Ngeno, D.K. et al., Editon Cons. J. Arts., Humanit. S. Stud., Double -Blind Peer Reviewed Journal

in 2012 from $1.49 \%$ in 2004 (Singal, 2016). Furthermore, the United Nation Children Education Fund (UNICEF, 2012) notes that despite well-articulated guidelines, the biggest challenge remains lack of toilets made to be friendly for children with disabilities and other facilities in most schools across the Country. The Pakistan Government urged the education providers and managers to put emphasis on the provision of suitable equipment for students with any type of impairment.

Nevertheless, severe cases of disability may be treated differently, but according to Tomlinson (2012), mainstreamed learning in schools seeks to remove the distinction between special and regular education completely. The intention was to provide an appropriate education for all learners in their local schools despite their level of disability. It involves a complete reconstitution of the educational system so that all schools would have the responsibility of providing the facilities, resources, and appropriate curriculum for all learners irrespective of their disabilities.

Friendly learning environments motivate joint learning among all children irrespective of disability. Pijl and Meijer (2016) assert that new buildings, for instance, classrooms with ramps for learners using wheelchairs and other tailored resources, help children with disabilities to move about, to read, to write and to hear the proceedings of lessons instruction. Well established learning environments provide push doors and bars to assist them in the bathrooms and handles to help them in the toilets/latrines. Doorsteps, dormitories and playgrounds should have ramps with recommended gradient where applicable. According to Ismail (2014), simple measures employed to promote change in schools attract learners with disabilities. Providing brightly painted rooms, clean floors, adequate ventilation, adequate lighting and assistive devices encourage learners' participation. These are aimed at ensuring that learners with disabilities are placed in conducive learning environments which are free from difficulties and complexities. The study by Pijl and Meijer (2016) did not examine the influence of appropriate physical resources on retention of pupils with disabilities in mainstreamed primary schools which the present study addressed. The focus of this research is based on the premise that if such facilities are provided, the retention of learners with disabilities would be enhanced.

Learners with special needs in education require specialised educational resources at individual and school levels, depending on the extent and nature of the disability. The high cost of special instruments for learners with special needs remains a hindrance to the Governments' goals to provide education for all in line with the global goal of Universal Primary Education (Owuor, 2014). Ministry of Education of the Republic of Kenya (2013) recognises that over time there has been a major backlog of infrastructure provision. Shortage of permanent classrooms still features as a problem, particularly when viewed among poor communities. On the same note, existing infrastructure was generally in poor condition due to lack of investment capital, poor construction standards and inadequate maintenance. Progress in the provision of physical facilities has been realised of late due to support given by the Constituency Development Fund. By and large, the highlighted resources were not specified to be appropriate for PWDs.

\section{METHODOLOGY}

This study utilised a survey research design. This design includes surveys and fact-finding inquiries of different kinds. The survey was carried out in Bomet County, Kenya. The target population for this study was teachers of mainstreamed primary schools in Bomet County. There were 76 mainstreamed primary schools in Bomet County during the period of this study. The targeted schools were composed of 76 headteachers and 840 teachers. This study utilised purposive sampling technique to select schools 


\section{Editon Consortium Journal of Arts, Humanities and Social Studies (ECJAHSS)}

Volume: 01 Issue: 03 | November -2019

ISSN: $2663-8525$

Received: 02.11.2019; Accepted 07.11.2019; Published: 05.12.2019 at www.editoncpublishing.org

Ngeno, D.K. et al., Editon Cons. J. Arts., Humanit. S. Stud., Double -Blind Peer Reviewed Journal

where various disabilities were mainstreamed. Lastly, simple random sampling was used to sample the respondents such that only three or four teachers were picked from each school according to the staffing establishment. To obtain the sample size of teachers, Yamane (1967) formula was applied. Therefore, the sample size for the study was 271 teachers. This study employed a questionnaire tool to collect primary data. The questionnaire items were examined for face and content validity by supervisors of Kabarak University. They scrutinised the items for purposes of clarity and verified whether they were addressing the topic of the study. On the other hand, reliability was measured using test-retest method using Pearson Product Moment Correlation Coefficient (PPMCC). The threshold was set at 0.7 coefficient.

\section{RESULTS}

\section{Appropriate Physical Resources}

Percentages were computed in order to access the respondents' views in relations to appropriate physical resources and retention of pupils with disabilities.

The findings are presented in Table 1.

Table 1: Percentages of Appropriate Physical Resources

\begin{tabular}{|l|l|l|l|l|l|}
\hline Statement & $\begin{array}{l}\text { SD } \\
(\%)\end{array}$ & $\begin{array}{l}\text { D } \\
(\%)\end{array}$ & $\begin{array}{l}\text { N } \\
(\%)\end{array}$ & $\begin{array}{l}\text { A } \\
(\%)\end{array}$ & $\begin{array}{l}\text { SA } \\
(\%)\end{array}$ \\
\hline $\begin{array}{l}\text { Appropriate mobility devices are available, for instance, wheelchairs, crutches, } \\
\text { strollers }\end{array}$ & 51.0 & 24.1 & 9.2 & 7.7 & 8.0 \\
\hline $\begin{array}{l}\text { There is an appropriate supply of light in the classrooms for visually impaired } \\
\text { learners }\end{array}$ & 31.8 & 26.1 & 6.9 & 5.4 & 29.9 \\
\hline There are appropriate hearing aids for hearing impaired learners in our school & 60.9 & 22.6 & 3.8 & 3.1 & 9.6 \\
\hline There are braille machines appropriate for visually impaired learners in our school 68.2 & 20.7 & 4.2 & 5.4 & 1.5 \\
\hline There are appropriate pocket boards' for PWDs in our school & 61.7 & 28.0 & 4.2 & 4.2 & 1.9 \\
\hline Appropriate pavements are available for PWDs in our school & 46.0 & 26.1 & 6.9 & 11.9 & 9.2 \\
\hline There are appropriate chairs for PWDs in our school & 51.7 & 26.1 & 8.0 & 8.8 & 5.4 \\
\hline There are appropriate desks for PWDs in our school & 51.3 & 35.6 & 5.4 & 4.6 & 3.1 \\
\hline Appropriate ramps are available for PWDs in our school & 44.8 & 25.3 & 5.4 & 18.0 & 6.5 \\
\hline There are appropriate toilets for PWDs in our school & 58.6 & 17.2 & 8.0 & 13.4 & 2.7 \\
\hline There are appropriate classrooms for PWDs in our school & 38.7 & 30.3 & 3.8 & 6.5 & 20.7 \\
\hline
\end{tabular}

Key: SD = Strongly Disagree; D=Disagree; N = Neutral; A = Agree; SA = Strongly Agree; and \%=Percentages.

Table 1 shows the computed percentages for the outlined items on the construct of physical resources. It was found that $75.1 \%$ strongly disagreed and disagreed that appropriate mobility devices were available; these include wheelchairs, crutches, embossers and strollers. This means that when these physical resources are lacking, retention of pupils with disabilities is hindered. This view was upheld by $83.5 \%$ and $88.9 \%$ of respondents who disagreed that there were appropriate hearing aids for hearing impaired learners in their schools and that there were braille machines appropriate for visually impaired learners. This could be the reason for the lack of retention of PWDs. The finding on physical resources concurs with that of McLeod (2018), who states that learners in a mainstreamed school should be accorded relevant facilities to enhance their education and optimal opportunities for their individual 


\section{Editon Consortium Journal of Arts, Humanities and Social Studies (ECJAHSS)}

Volume: 01 Issue: 03 | November -2019

ISSN: $2663-8525$

Received: 02.11.2019; Accepted 07.11.2019; Published: 05.12.2019 at www.editoncpublishing.org

Ngeno, D.K. et al., Editon Cons. J. Arts., Humanit. S. Stud., Double -Blind Peer Reviewed Journal

upgrade. It was also noted that Singal (2016) observations agree with the findings of this study by noting that in Pakistan, the retention rate of PWDs in regular schools was slowly increasing. However, it was noted that basic school infrastructure continued to remain poor in that county. This could affect retention of PWDs. This is because when basic school infrastructure for PWDs is lacking, retention could be hampered.

The finding revealed that respondents disagreed that there were appropriate classrooms and toilets geared towards PWDs in their mainstreamed schools as observed by $69.0 \%$ and $75.8 \%$ of respondents, respectively. It can be debated that the absence of appropriate physical facilities could affect retention of PWDs. It was further noted that Pijl and Meijer (2016) reiterate that new buildings, for instance, classrooms with ramps and other resources help children with disabilities to move about, to read, to write, to hear and to follow the proceedings of instruction. This was in full agreement with the finding of this section of the study. Despite this requirement, $70.1 \%$ and $72.1 \%$ of respondents in this study disagreed that appropriate ramps and pavements were available for PWDs in their schools. This means that movements of PWDs during learning were hampered and could affect retention. It was also observed that $77.8 \%$ and $86.9 \%$ of respondents in the same study disagreed that appropriate chairs and desks for PWDs in their schools were available. This could affect retention of PWDs as they were not in a position to effectively study without appropriate resources.

Respondents in this study disagreed that there was an appropriate supply of light in the classrooms for visually impaired learners (57.9\%) as well as lack of appropriate 'pocket-boards' for PWDs in their schools (89.7\%). This shows that learners who are visually impaired may not be in a position to learn in the absence of adequate classroom lighting. Ismail (2014) and Attig and Hopkins (2014) recommends that providing brightly painted rooms, clean floors, adequate ventilation, adequate lighting and assistive devices encourage all learners' participation. The researchers further opine that these are aimed at ensuring that learners with disabilities are placed in conducive learning environments which are free from difficulties and complexities.

Correlation Analysis between Appropriate Physical Resources and Retention of Pupils with Disabilities

Pearson correlation test was used to investigate whether there exists a significant influence between appropriate physical resources and retention of pupils with disabilities. The analysis was tested at 0.05 level of significance. The findings are presented in Table 2.

Table 2: Correlation between Appropriate Physical Resources and Retention of Pupils with Disabilities

\begin{tabular}{|c|c|c|}
\hline & & \begin{tabular}{|l|l|}
$\begin{array}{l}\text { Retention of pupils Appropriate Physical Resources } \\
\text { with Disabilities }\end{array}$ & \\
\end{tabular} \\
\hline & Pearson Correlation & $0.828^{* *}$ \\
\hline Retention of pupils with disabilities & Sig. (2-tailed) & .000 \\
\hline & $\mathrm{N}$ & 261 \\
\hline
\end{tabular}

The study findings indicated that there was evidence of a positive and statistically significant influence of appropriate physical resources on retention of pupils with disabilities $\left(r=0.828^{* *} p<0.05\right)$. This meant that when appropriate physical resources are provided to pupils with disabilities, their retention in those schools improves. Kamau (2015) 


\section{Editon Consortium Journal of Arts, Humanities and Social Studies (ECJAHSS)}

Volume: 01 Issue: 03 | November -2019

ISSN: $2663-8525$

Received: 02.11.2019; Accepted 07.11.2019; Published: 05.12.2019 at www.editoncpublishing.org

Ngeno, D.K. et al., Editon Cons. J. Arts., Humanit. S. Stud., Double -Blind Peer Reviewed Journal

found that there was a significant relationship between the learning environment and the performance of learners with disabilities in Kamukunji public primary schools $(r=0.504$, $p<\alpha=0.05)$. This implies that the provision of a conducive learning environment could affect retention of PWDs.

\section{Regression Analysis}

Influence of appropriate physical resources on retention of pupils with disabilities in was analysed using regression and presented in Table 3.

Table 3: Regression Coefficients ${ }^{\mathrm{a}}$

\begin{tabular}{|l|l|l|l|l|}
\hline Model & Unstandardised Coefficients & t & Sig. \\
\hline & B & Std. Error & & \\
\hline (Constant) & -.179 & .055 & -3.266 & .001 \\
\hline & & & & \\
\hline Appropriate physical resources & .192 & .044 & 4.394 & .000 \\
\hline a. Dependent Variable: Retention of pupils with disabilities & & \\
\hline
\end{tabular}

It was found that appropriate physical resources significantly influence retention of pupils with disabilities by $19.2 \%$

\section{Hypothesis Testing}

$\mathrm{H}_{01}$ : There is no statistically significant influence of appropriate physical resources on retention of pupils with disabilities in mainstreamed primary schools in Bomet County, Kenya.

According to Table 3 , the $p$-value $(p=0.000)$ for the variable appropriate physical resources is less than 0.05 alpha level. The null hypothesis was rejected, and the decision was made that appropriate physical resources have a significant influence on the retention of pupils with disabilities in mainstreamed primary schools in Bomet County, Kenya. This indicates that the availability of appropriate physical resources has a positive influence on retention on pupils with disabilities. However, it means that when these resources are lacking, the retention of PWDS could be affected negatively.

The study by Global Partnership for Education (2017) suggests key barriers affecting education for children with disability to include lack of infrastructure, learning material, and strategies on inclusive education. These also include lack of financial resources and lack of inter-ministerial coordination. These barriers were cited to hamper education in many countries of the world. Bomet County, where this research on the status of retention of pupils with disabilities was concentrated, is not exclusive of these barriers as part of the extraneous factors affective effective education for pupils with disabilities in mainstreamed or integrated primary schools.

\section{CONCLUSION}

In view of the key findings of this study, the supply of appropriate resources remains a major factor that is viewed to promote retention of pupils with disabilities. The Pearson Product Moment Correlation Coefficient's test was applied to investigate whether there was a significant relationship which existed among the variables. The findings indicated that there was evidence of a positive and statistically significant relationship between appropriate physical resources and retention of pupils with disabilities $\left(r=0.828^{* *} p<0.05\right)$. This means that when appropriate physical resources are provided to pupils with disabilities, their retention of pupils with disabilities in mainstreamed schools improve. However, lack of these resources has 


\section{Editon Consortium Journal of Arts, Humanities and Social Studies (ECJAHSS)}

Volume: 01 Issue: 03 | November -2019

ISSN: $2663-8525$

Received: 02.11.2019; Accepted 07.11.2019; Published: 05.12.2019 at www.editoncpublishing.org

Ngeno, D.K. et al., Editon Cons. J. Arts., Humanit. S. Stud., Double -Blind Peer Reviewed Journal

been proven through the findings of this research that they cause drop out of PWDs from their schools.

\section{RECOMMENDATIONS}

Based on the study findings, it was the following recommended that appropriate physical resources such as classrooms, toilets, dining halls, dormitories, laboratories and libraries in order to promote retention of pupils with disabilities be provided by school administrators.

\section{References}

Attig, G., \& Hopkins, J. (2014). Assessing schools for inclusive education: A guide for program managers in East Asia and the Pacific. Bangkok: UNICEF.

Baxter, L. A., \& Babbie, E. (2013). The basics of communication research. Boston: Wadsworth/Engage Learning.

Bomet County Integrated Development Plan. (2013). First County Integrated Development Plan. Bomet: Bomet County.

Filmer, D. (2008). Disability, poverty, and schooling in developing countries: Results from 14 household surveys. The World Bank Economic Review, 22(1), 141-163.

Global campaign for education. (2014). Equal right, equal opportunity: Inclusive education for children with disabilities. Johannesburg: Handicapp international.

Global Partnership for Education. (2017). Disability and inclusive education. A stocktake of education sector plans and GPE-Funded grants. Washington, DC: Global Partnership for Education.

Ismail, R. (2014). Welcoming schools: A Lebanese model. American University of Beirut. Lebanon: Unpublished master's thesis.

Kamau, B. N. (2015). Institutional related factors affecting performance of learners with special needs In Kamukunji Public Primary Schools In Kenya. University of Nairobi: Published Research Project.

Kogei, J. K. (2013). Factors influencing enrolment of learners with disabilities in an inclusive education in primary schools in Nandi South District Kenya. University Of Nairobi: Unpublished Thesis.

MacGuine, \& Molbjerg. (2011). Human resource development. Theory and practice. London: Sage publications.

McLeod, S. (2018). Questionnaire. Retrieved on January 20, 2018, from Simply Psychology: https://www.simplypsychology.org/questionnaires.html

Ministry of Education. (2013). The national special needs education policy framework. Nairobi: Government printers.

National Coordinating Agency for Population and Development, \& Kenya National Bureau of Statistics. (2008). Kenya National Survey for Persons with Disabilities: Main Report. Retrieved from http://www.ncpd.go.ke/wp-content/uploads/2017/09/2007-Kenya-National-Survey-onPersons-with-Disabilities.pdf

National Council for Population and Development. (2017). 2015 Kenya National Adolescents And Youth Survey (NAYS). Nairobi, Kenya: NCPD. 


\section{Editon Consortium Journal of Arts, Humanities and Social Studies (ECJAHSS)}

Volume: 01 Issue: 03 | November -2019

ISSN: $2663-8525$

Received: 02.11.2019; Accepted 07.11.2019; Published: 05.12.2019 at www.editoncpublishing.org

Ngeno, D.K. et al., Editon Cons. J. Arts., Humanit. S. Stud., Double-Blind Peer Reviewed Journal

Walsh, T., \& Thomas, K. (2015). Children with special needs and the right to education. The University of Queensland: Thesis.

Khumalo, S., \& Hodgson, T. F. (2015, April 14). The right to education for children with disabilities in South Africa: SECTION27's action from national research and litigation strategies to international advocacy. Retrieved on January 31, 2018, from Right to education: http://www.right-toeducation.org/blog/right-education-children-disabilities-south-africa-section27-s-action-nationalresearch.

Owuor, L. O. (2014). Determinants of inclusion of learners with special needs in public primary schools in Kisumu Municipality, Kisumu County. University of Nairobi: Unpublished Research Project.

Pijl, S., \& Meijer, J. W. (2016). Inclusive education: A global agenda. London, Great Britain: Routledge.

Richardson, S. (2013, July 15). China: End discrimination, exclusion of children with disabilities. Retrieved on January 31, 2018, from Human rights watch: https://www.hrw.org/report/2013/07/15/long-they-letus-stay-class/barriers-education-persons-disabilities-china

Singal, N. (2016). Education of children with disabilities in India and Pakistan: Critical analysis of developments in the last 15 years. University of Cambridge: Unpublished Thesis.

Stough, L. P. (2013). Special thinking in special settings: A qualitative study of experts in special education. Journal of Special Education, 9(36), 206-222.

Tomlinson, T. (2012). A sociology of special education. London: Routledge.

UNICEF. (2012). WASH for school children. State-of-the-art in Afghanistan, Bangladesh, Bhutan, India. Nepal: UNICEF Regional Office for South.

Universal Declaration of Human Rights. (1948). Retrieved from https://www.un.org/en/universaldeclaration-human-rights/

Von Bertalanffy, L. (1968). General system theory: Foundations, development, applications. New York: George Braziller.

Yamane, T. (1967). Statistics: An introductory analysis, 2nd Ed., New York: Harper and Row. 